\title{
KEMUNGKINAN PEMANFAATAN BEBERAPA JENIS BAMBU TERTENTU, BERDASARKAN POLA PENYUSUNAN BERKAS PEMBULUH, SEBAGAI BAHAN BAKU PULP DAN KERTAS
}

\author{
(Possible Uses of Several Particular Bamboo Species, Scrutinized \\ through the Pattern of Their Vascular Bundle Arrangement, \\ as Raw Material Pulp and Paper)
}

\author{
Oleh/By : \\ Nani Nuriyatin \& Kurnia Sofyan \\ Program Pascasarjana Studi Ilmu Pengetahuan Kehutanan IPB \\ Jl. Lingkar Akademik Kampus IPB Darmaga, Bogor 16680 \\ Telp. +62251862677 Fax. +62 251862256 \\ e-mail : nani.nuriyatin@yahoo.com
}

Diterima 17 Januari 2011, disetujui 7 Oktober 2011

\begin{abstract}
The abundant availability of bamboos in Indonesia has prompted their possible uses as raw material for pulp and paper. This is expected to replace its corresponding conventional raw materials (i.e. woods), which nowadays tend to be dwindling, scarce, and limited. In relevant, this research aims to assess the suitability of bamboo stem for such comprision several species. The grouping of bamboo species brought out the results,i.e. Arundinaria bundsii and Arundinaria javonica as pattern 1; Cephalostachyum pergracile and Melocanna baccifera as pattern 2; Dendrocalamus strictus and Dendrocalamus giganteus as pattern 3; and Dendrocalamus asper and Gigantochloa apus as patterns 3 and 4). In assessing the bamboo suitability for pulp and paper, an approach was taken whereby the bamboo species in the particular pattern was examined of fiber dimensions (i.e. fiber length, fiber flexibility, rigidity coefficient, Runkel ratio, and Mublstep ratio). To evaluate whether there were significant differences in the examination/determination results among those 4 patterns, the analysis of variances (probability levels)with completely standardized one-factor design was employed followed with the different range test of the resulting means (i.e. Tuckey procedures). The factor was those four bamboopatterns.

Results revealed that each of those fourpatterns based on fiber length and felting power belonged to class I, indicating as the most favourable for pulp and paper. Meanwhile, other scrutiny based on fiber flexibility, rifidity coefficient, Runkel ratio, and Mublstep ratio turnd out that all the patterns belonged to class III. Further, bamboo species catagoried as pattern I exbibited species characters such as affording the bighest fiber flexibility and lowest rigidity coefficient as well as runkel ratio compared to those of the ather patterns. Meanwhile, bamboo species in pattern 4 exbibited the bighest fiber length and felting power. Ultimately, assessment on the overall fiber dimensions and their derived values came about that all the four bamboo pattern belonged to class III, as indicative qualities of the resulting pulp and paper However, to make sure whether such indication proved true, further in-depth research on the pulp and paper processing from those entire bamboos (pattern 1 until4) deserves carrying out.
\end{abstract}

Keyword: Abundant availability, pulp and paper, bamboo spesies, patterns of vascular bundles arrangement, fiber dimension and their derivative values. 


\begin{abstract}
ABSTRAK
Ketersediaan bahan baku bambu yang berlimpah di Indonesia telah mendorong kemungkinan penggunaan bambu sebagai bahan baku untuk pulp dan kertas. Hal ini diharapkan untuk menggantikan bahan baku konvensional (dalam hal ini kayu) yang mana sekarang cenderung menurun, langka dan terbatas. Terkait dengan hal ini, penelitian bertujuan untuk menilai kesesuaian batang bambu dari spesies tertentu untuk hal trsebut diatas. Pengelompokan spesies bam̄bu menetapkan hasil yaitu Arundinaria bundsii dan Arundinaria javonica sebagai pola 1, Cephalostachyum pergracile dan Melocanna baccifera sebagai pola 2, Dendrocalamus strictus dan Dendrocalamus giganteus sebagai pola 3, Dendrocalamus asper dan Gigantocbloa apus sebagai pola 3 dan 4. Dalam penilaian kesesuaian bambu untuk pulp dan kertas, sebuah pendekatan diambil dengan cara spesies-spesies bambu dalam pola tertentu diamati dimensi serabutnya (yaitu panjang serabut, fleksibilitas serabut, koefisien kekakuan, nisbah Runkel dan nisbah muhlstep). Untuk mengevaluasi apakah ada perbedaan signifikan dalam pengamatan/ penentuan hasil diantara ke-4 pola, analisis keragaman berpola acak lengkap satu factor diterapkan yang diikuti oleh uji perbedaan rata-rata hasil tersebut (prosedur Tuckey). Dan sebagai factor adalah 4 pola.

Hasilnya menyatakan bahwa setiap pola berdasarkan panjang serabut dan daya tenun termasuk ke dalam kelas I, menunjukkan sebagai bahan terbaik untuk pulp dan kertas. Sementara pencermatan berdasarkan fleksibilitas serabut, koefisien kekakuan, nisbah Runkel, dan nisbah Muhlstep seluruhnya termasuk ke dalam kelas III. Lebih lanjut, spesies bambu dikatagorikan sebagai pola I menunjukkan karakter spesies seperti menghasilkan fleksibilitas serabut tertinggj dan koefisien kekakuan dan nisbah Runkel terendah dibandingkan dengan pola-pola lain. Sementara itu spesies bambu dalam pola 4 memiliki panjang serabut dan daya tenun tertinggi. Pada akhirnya, pencermatan pada seluruh dimensi serabut dan nilai turunannya menyatakan bahwa seluruh 4 pola bambu termasuk ke dalam kelas III sebagai indikasi mutu dari pulp dan kertas yang dihasilkan. Bahkan untuk menjamin apakah indiksi ini benar, memerlukan riset mendalam pada proses pembuatan pulp dan kertas dari seluruh bambu (pola 1 sampai 4) yang sebaiknya dikerjakan.
\end{abstract}

Kata kunci: Ketersediaan yang berlimpah, pulp dan kertas, spesies bambu, susunan pola ikatan pembuluh, dimensi serabut dan turunannya.

\title{
I. PENDAHULUAN
}

Keperluan serat pulp untuk pembuatan kertas terus meningkat. hampir di seluruh dunia, termasuk di Indonesia. Hal ini dipicu dengan ketersediaan kayu khususnya dari hutan alam yang semakin terbatas dengan harga semakin mahal. Khusus untuk Indonesia yang berada di daerah tropis, tanaman bambu merupakan salah satu alternatif pilihan bahan baku pulp dan kertas paling penting (Lybeer et al. 2006). Bambu memiliki keunggulan jika digunakan sebagai bahan baku kertas antara lain adalah laju pertumbuhan yang cepat dan mudah diputihkan setelah diolah menjadi pulp menggunakan proses kraft karena tekstur bambu sebagai tanaman monokotil (di mana lebih banyak jaringan parenkim) sehingga tidak sepadat kayu (Stephenson 1952; Casey 1980). Sebaliknya kerugiannya adalah adalah kandungan lignin yang lebih tinggi dan keberadaan jaringan parenkim tersebut berakibat konsumsi bahan kimia pemasak selama pengolahan pulp menjadi lebih tinggi daripada pemasakan kayu. Di samping itu serabut bambu lebih kaku dibanding ikatan serat kayu karena dinding sel yang tebal serta lumen yang sempit (Rowell et al 1997). Sementara itu Pasaribu dan Silitonga (1974) dan Patt et al. (2005) menyatakan bahwa selain komponen kimia dan kondisi pengolahan, morfologi serat bahan berlignoselulosa juga merupakan salah satu faktor yang perlu diperhatikan dalam pembuatan pulp dan kertas karena komposisi jaringan tanaman 
dalam sel yang beragam dalam ketebalan dinding sel mempunyai efek yang besar terhadap penggunaan bambu dalam proses industri kayu. Secara khusus serat yang panjang, fleksibilitas yang tinggi, dan nisbah tebal dinding terhadap lumen yang rendah adalah dikehendaki dalam pembuatan pulp dan kertas (Xu et al. 2005).

Di antara berbagai jenis bambu yang ada ternyata bambu memiliki berbagai pola ikatan pembuluh. Menurut Grosser dan Liese (1971), pola ikatan pembuluh yang terdapat pada bambu terdiri atas 4 jenis yaitu tipe 1,2,3 dan 4 yang menjadi pembeda antar genus dan spesies. Pada bagian pangkal batang tidak menutup kemungkinan tersusun atas lebih dari 1 pola ikatan pembuluh seperti yang terdapat pada pola/tipe 2,3 dan 4. Gabungan pola/tipe yang dapat terjadi pada bagian pangkal adalah pola 2 bergabung dengan pola 3 seperti dalam genus Schizostachyum, Melocanna, dan Teinostachyum. Sementara gabungan pola lain seperti pola 3 bergabung dengan pola 4 dapat muncul pada genus Bambusa, Dendrocalamus, Gigantochloa, dan Thyrsostachys. Dalam hal ini khusus untuk genus Cephalostachyum dari mulai bagian pangkal ke bagian ujung murni tersusun atas satu pola, yaitu pola 2 demikian pula yang terjadi pada genus Oxynanthera spp yang memiliki pola 3 murni pada keseluruhan bagian batang. Diantara ke-4 pola ikatan yang ada, setiap pola memiliki ciri yang berbeda dan perbedaan ini signifikan diantara spesies dan genus. Hal ini dapat berdampak nyata terhadap sifat pengolahan pulp bambu dan sifat pulp/kertasnya.

Terkait dengan seluruh uraian, telah dilakukan pencermatan pola ikatan pembuluh bambu, sehubungan dengan pemanfaatannya untuk pulp dan kertas. Bahan baku bambu dalam penelitian dipilih berdasarkan keterwakilan pola-pola tersebut yang dimiliki oleh bambu yaitu Arundinaria bundsii dan Arundinaria javonica (mewakili pola 1), Melocanna baccifera dan Cephalostachyum pergracile (mewakili pola 2), Dendrocalamus gigantus dan Dendrocalamus strictus (mewakili pola 3) serta Dendrocalamus asper dan Gigantocbloa apus (mewakili pola 3 dan 4). Tujuan penelitian adalah mendapatkan informasi secara lengkap mengenai kemungkinan penggunaan bambu yang terwakili dalam bentuk pola ikatan pembuluh sebagai bahan baku pulp dan kertas serta menentukan karakteristiknya pada setiap pola ikatan pembuluh.

\section{BAHAN DAN METODE}

\section{A. Bahan}

Bahan baku yang digunakan dalam penelitian adalah bambu terdiri dari 4 macam pola ikatan pembuluh dimana masing-masing pola terwakili oleh 2 jenis bambu yaitu berturutturut Arundinaria bundsii (Ab), Arundinaria javonica (Aj); Melocanna baccifera (Mb), Cephalostachyum pergracile (Cp); Dendrocalamus giganteus (Dg), Dendrocalamus strictus (Ds); dan Dendrocalamus asper (Da), Gigantochloa apus (Ga). Dalam hal ini khusus untuk Dendrocalamus asper (Da) dan Gigantochloa apus ( $\mathrm{Ga}$ ) mewakili pola 3 dan 4 karena adanya perbedaan pola antar bagian batang. Pengambilan contoh bambu dilakukan di Kebun Raya Bogor dan sekitar lokasi Fakultas Kehutanan Institut Pertanian Bogor.

\section{B. Penetapan Contoh Uji}

Contoh uji ditetapkan pada jenis-jenis bambu yang mewakili pola ikatan pembuluh 1 sampai 4 dengan dibantu panduan dari Grosser dan Liese (1971). Contoh uji tersebut diambil 
dari bagian pangkal, tengah dan ujung pada tengah-tengah ruas dengan ulangan masingmasing 3 kali berupa bagian bambu kecuali untuk untuk Arundinaria bundsii dan A. javonica hanya dilakukan pada bagian tengah bambu saja karena keterbatasan bahan baku terkait dengan kecilnya diameter batang jenis bambu tersebut $( \pm 1.63 \mathrm{~cm})$.

\section{Penyiapan Contoh}

Semua contoh dimaserasi dengan metode $S$ chultze (Sass, 1951) menggunakan $\mathrm{KClO}_{3}$, $\mathrm{HNO}_{3} 50 \%$, dan pewarna safranin $2 \%$.

\section{Pencermatan Karakteristik Hasil Maserasi Contoh}

Karakteristik yang dicermati mencakup dimensi serat dan nilai turunannya. Dimensi serat yang diukur adalah panjang serat (L), diameter serat (D), diameter lumen (l), dan tebal dinding sel (w). Tahap selanjutnya adalah menghitung nilai turunan dimensi serat (Casey 1980) yang meliputi nisbah Runkel $(2 \mathrm{w} / \mathrm{l})$, daya tenun $(\mathrm{L} / \mathrm{D})$, nisbah muhlsteph $\left[\left(\mathrm{D}^{2}-\mathrm{I}^{2}\right) / \mathrm{D}^{2}\right]$ x 100, fleksibilitas (1/D), koefisien kekakuan (w/D).

\section{E. Analisis Data}

Data dimensi serat dan nilai turunan dimensi dari beberapa macam bambu (yang diklasifikasikan ke dalam 4 macam pola ) diolah dengan analisa keragaman berfola acak lengkap satu faktor (Lampiran 2) dilanjutkan uji Tuckey (Lampiran 3), dan sebagai faktor adalah pola penyusunan ikatan pembuluh sebanyak 4 buah. Hasil olahan tersebut lalu dibandingkan dengan mengacu kepada standar persyaratan kayu sebagai bahan baku pulp dan kertas (Lampiran 1).

\section{HASIL DAN PEMBAHASAN}

\section{A. Hasil Pengukuran Dimensi Serabut dan Nilai Turunannya}

Pengukuran dimensi serabut bambu pada berbagai pola memberikan hasil seperti yang tercantum pada Tabel 1. Dalam hal ini pengamatan difokuskan pada pola bambu (tidak kepada jenis bambu), sehingga nilai dimensi serat dan turunannya juga dihitung berdasarkan pola. Untuk lebih jelas, hasil yang diperoleh seperti tercantum pada Tabel 1 dan 2 . Terlihat bahwa panjang serabut (serat) bambu pada pola 1 memiliki nilai yang terendah sedangkan panjang serabut cenderung meningkat dengan urutan pola ke 2, 3, hingga ke 4 dimana pada pola 4 memiliki nilai yang tertinggi. Hal ini diperkuat berdasarkan hasil analisa keragaman dan uji Tuckey (Lampiran 3). Dalam hal diameter rongga (lumen) serabut bambu ternyata nilainya tertinggi pada pola 1 dan cenderung menurun dengan urutan pola ke 3, 4 hingga ke dua (terendah). Mengenai diameter serabut terlihat nilai diameter yang tertinggi dimiliki oleh pola 4 dan berturut-turut menurun nilainya mulai dari pola 3, pola 1 hingga pola 2. Demikian pula ketebalan dinding sel menunjukkan kecenderungan yang tidak teratur dengan dinding serabut yang paling tebal dimiliki oleh bambu dengan pola 4 dan berturut-turut cenderung menurun dengan urutan pola ke 3 , pola 2 hingga ke pola 1 (terendah). 
Kemungkinan Pemanfaatan Beberapa Jenis Bambu Tertentu, Berdasarkan ..... (Nani Nuriyatin \& Kurnia Sofyan)

Tabel 1. Rerata dimensi serat bambu (mikron) pada pola 1 hingga 4 dari 8 jenis bambu

Table 1. Average fibre dimension of bamboo fibre (micron) at pattern 1 until 4 overall covering 8 bamboospecies

\begin{tabular}{|c|c|c|c|c|c|}
\hline $\begin{array}{l}\text { Jenis bambu } \\
\text { (Bamboo species) }\end{array}$ & $\begin{array}{l}\text { Pola*) } \\
\text { (Pattern) }\end{array}$ & $\begin{array}{c}\text { Panjang serabut } \\
\text { (Fiber lengtb) } \\
\text { L }\end{array}$ & $\begin{array}{c}\text { Diameter } \\
\text { serabut } \\
\text { (Fibre } \\
\text { diameter) } \\
\text { D }\end{array}$ & $\begin{array}{c}\text { Tebal } \\
\text { dinding } \\
\text { (Fibre wall) } \\
\text { w }\end{array}$ & $\begin{array}{c}\text { Lebar } \\
\text { rongga } \\
\text { (Lumen } \\
\text { diameter) } \\
1 \\
\end{array}$ \\
\hline $\mathrm{Ah}$ dan $\mathrm{Aj}(\mathrm{t})$ & 1 & 2373.626 & 17.241 & 5.741 & 5.759 \\
\hline $\mathrm{Mb}$ dan $\mathrm{Cp}_{\mathrm{p}}(\mathrm{p}, \mathrm{t}, \mathrm{u})$ & 2 & 2571.403 & 15.776 & 6.171 & 3.434 \\
\hline $\begin{array}{l}D g(p, t, u), D s(p, t, u), D a \\
(t, u), G a(u)\end{array}$ & 3 & 2841.406 & 17.350 & 6.752 & 3.845 \\
\hline $\mathrm{Da}(\mathrm{p}), \mathrm{Ga}(\mathrm{t}, \mathrm{u})$ & 4 & 3734.514 & 18.422 & 7.317 & 3.787 \\
\hline
\end{tabular}

Keterangan (Remarks):

*) Terkait dengan pola ikatan pembuluh pada bambu (Related to the pattern of vascular bundle of bamboo in bamboo stem/culm; Pola (patterns) 1, 2, 3, 4 berarti pada bagian batang bambu terdapat berturut-turut berkas pembuluh sebanyak 1,2,3,4 (imply there are consecutively vascular bundles 1, 2, 3, and 4 in the portion of bamboo culm). $\mathrm{Ah}=$ Arundinaria bundsii; $\mathrm{Aj}=$ Arundinaria javanica $; \mathrm{Mb}=$ Melocanna baccifera $; \mathrm{Cp}=$ Cephalostachyum pergracile $; \mathrm{Dg}=$ Dendrocalamus giganteus $; \mathrm{Ds}=$ Dendrocalamus strictus $; \mathrm{Da}=$ Dendrocalamus asper, $\mathrm{Ga}=$ Gigantochloa apus; $\mathrm{p}=$ bagian pangkal (lowerportion) $\mathrm{t}=$ bagian tengah (middle portion) $\mathrm{u}=$ bagian ujung (upper portion), masing-masing bagian tersebut diambil dari bagian tengah ruas bambu (each of these portion taken approximately halfway axially between internodes at bamboo stem / culm); (p, t, u), (t,u), (t), (p), (u) masing-masing mencakup berturut-turut / Each covers $(p, t, u)$ portions, $(t, u)$ portions, tportion, pportion, and uportion, respectively; mikron (micron) $=10^{-6} \mathrm{~m}$ (meter).

Tabel2. Nilai turunan dimensi serat 8 jenis bambu dirinci menurut 4 macam pola Table 2. Derived fiber dimension values of 8 bamboo species, scrutinized into 4 patterns

\begin{tabular}{|c|c|c|c|c|c|}
\hline $\begin{array}{c}\text { Pola } \\
\text { Pattern) }\end{array}$ & $\begin{array}{c}\text { Daya tenun } \\
\text { (Felting power) } \\
\text { L/D }\end{array}$ & $\begin{array}{c}\text { Fleksibilitas } \\
\text { serat } \\
\text { (Fiber } \\
\text { flexibility) } \\
\text { L/D }\end{array}$ & $\begin{array}{c}\text { Koef. kekakuan } \\
\text { (Rigidity coeff) } \\
\text { w/D }\end{array}$ & $\begin{array}{c}\text { Nisbah Runkel } \\
\text { (Runkel ratio) } \\
2 \mathrm{w} / 1\end{array}$ & $\begin{array}{c}\text { Nisbah } \\
\text { Muhlsteph } \\
(\text { Mublstep ratio }) \\
{\left[100\left[\left(\mathrm{D}^{2}-\mathrm{I}^{2}\right) / \mathrm{D}^{2}\right]\right.}\end{array}$ \\
\hline 1 & 140.294 & 0.329 & 0.336 & 2.125 & 88.939 \\
2 & 162.222 & 0.217 & 0.391 & 3.788 & 95.093 \\
3 & 168.435 & 0.224 & 0.388 & 4.023 & 94.416 \\
4 & 205.366 & 0.209 & 0.396 & 4.245 & 95.237 \\
\hline
\end{tabular}


Mengulas satu persatu terhadap nilai dimensi dan turunannya antara lain yang pertama adalah panjang serabut. Panjang serabut yang lebih dari 2000 mikron berindikasi kalau diolah menjadi pulp dan kertas memiliki keteguhan sobek kertas yang tinggi yang artinya semakin panjang serabut maka keteguhan sobeknyapun akan semakin tinggi (Haygreen dan Bowyer 1996). Demikian pula daya tenunnya akan memiliki mutu yang baik karena jalinan antar seratnya akan sangat baik pada proses pembentukan kertas. Kekurangan yang dimiliki oleh bambu sebagai bahan dasar pulp dan kertas dalam penelitian ini adalah nilai fleksibiltas yang rendah (di bawah 0.5), koefisien kekakuan yang tinggi $(>0.15)$, nisbah Runkel yang bernilai tinggi (lebih dari 1) dan nisbah Muhlstep yang juga bernilai tinggi pula (lebih dari 80). Dengan nilai fleksibilitas yang rendah maka kertas yang dihasilkan tidak plastis demikian pula dengan koefisien kekakuan yang tinggi maka kertas yang dihasilkan akan kaku, dan serat sukar menggepeng pada saat pembentukan lembaran kertas. Apabila melihat hasil olahan data (Lampiran 2) terutama panjang serabut untuk berbagai pola ikatan pembuluh maka terlihat bahwa panjang serabut pola 1 sama dengan pola 2 dan 3 namun berbeda dengan pola 4 . Melihat pada nilai panjang serabut yang dimiliki oleh pola 1,2 dan 3 dengan 4 ternyata panjang serabut yang dimiliki pola 4 mempunyai nilai yang paling panjang artinya bahwa bambu yang memiliki pola 4 bila diolah menjadi pulp dan kertas berindikasi mempunyai kekuatan sobek yang paling tinggi dibandingkan dengan pola-pola lain. Panjang serabut merupakan salah satu faktor untuk mengontrol sifat-sifat kekuatan kertas karena terkait dengan kemampuan mengikat dan jalin-menjalin diantara serabut (Wangaard dan Woodson 1973) dalam Mohmod et al. (1972). Lapierre (2006) juga menegaskan bahwa panjang serabut berpengaruh positif terhadap kekuatan kertas.

Mengamati nilai daya tenun untuk ke-4 pola ikatan pembuluh pada bambu ternyata memberikan pengaruh yang nyata (Lampiran 2). Melalui uji Tukey (Lampiran 3) terlihat bahwa nilai daya tenun untuk pola 1,2 dan 3 berbeda dibandingkan dengan daya tenun pada pola 4. Melihat nilai daya tenun untuk seluruh pola terdapat kecenderungan nilai daya tenun yang meningkat dari mulai dari pola 1 sampai pola 4 . Hal ini berarti bahwa kertas yang akan dihasilkan dari bambu dengan pola 4 cenderung akan memberikan susunan serat kertas yang lebih rapat sehingga kekuatan sobeknya lebih tinggi. Semakin tinggi nilai daya tenun maka kertas akan memiliki kekuatan lentur yang lebih baik yang mengindikasikan berpengaruh positif terhadap keteguhan lipat kertas tersebut.

Nilai fleksibilitas, berdasar analisa keragaman nilai tersebut dipengaruhi secara nyata $(\mathrm{P}<0.05)$ menurut pola ikatan pembuluh (Lampiran 2). Melalui uji nilai tengah ternyata nilai fleksibilitas pola 1 berbeda dengan pola-pola lain. Dengan uji Tukey (Lampiran 3) terlihat bahwa nilai fleksibilitas pola 2 sama dengan nilai fleksibilitas pola 3 dan 4 . Fleksibilitas merupakan nisbah diameter lumen dengan diameter serabut, nilai fleksibilitas yang semakin besar maka semakin baik kualitas serabut. Pada pola 1 terlihat bahwa nilai fleksibilitas paling tinggi yang juga berarti bahwa diameter lumennya paling lebar sehingga mudah untuk menggepeng dan kertas yang dihasilkan memiliki kekuatan panjang putus yang baik walaupun dalam hal ini keseluruhan nilai fleksibilitas masih jauh di bawah persyaratan kelas III. Menurut Xu et al. (2005) dengan nilai fleksibilitas yang tinggi diharapkan akan mempunyai efek positif pada kekuatan tarik dan sobek.

Sementara hasil analisa keragaman untuk nilai koefisien kekakuan menunjukkan bahwa nilai koefisien kekakuan untuk berbagai pola menunjukkan adanya perbedaan (Lampiran 2). Melihat lebih jauh pada uji Tuckey (Lampiran 3) terlihat bahwa koefisien kekakuan pola 1 
berbeda dengan nilai kekakuan pada pola-pola lain namun nilai koefisien kekakuan pola 2 sama dengan nilai koefisien kekakuan pada pola 3 dan 4. Melalui uji Tuckey terbaca bahwa nilai koefisien kekakuan untuk pola 1 paling rendah dibanding dengan nilai koefisien kekakuan untuk pola lain yang berarti bahwa kualitas kertas yang akan diperoleh dari bambu yang mempunyai pola 1 relatif cenderung memiliki kerapatan yang lebih rendah sehingga lembaran kertas yang dihasilkan lebih lentur, ketahanan lipatnya lebih baik dan cenderung memiliki ketahanan tarik yang lebih baik.

Berdasarkan hasil analisa keragaman pada Lampiran 2 ternyata pola ikatan pembuluh pada bambu tidak berpengaruh nyata terhadap nilai nisbah Runkel walaupun dalam hal ini terdapat kecenderungan bahwa nilai nisbah Runkel semakin meningkat nilainya dari mulai pola ikatan pembuluh 1 sampai ke pola 4 . Diantara ke-4 pola yang ada maka nisbah runkel pola 1 memiliki nilai yang terendah artinya dibandingkan pola-pola lain maka nisbah Runkel pola 1 adalah yang terbaik. Hal ini berarti bahwa serat bambu pada pola 1 memiliki dinding sel yang paling tipis dengan diameter lumen yang paling besar. Dengan nisbah Runkel yang paling rendah maka kertas yang dibentuk dari bambu yang memiliki pola 1 akan bersifat relatif lebih baik dalam kekuatan tarik dan lipat dibandingkan pola-pola lain.

Bila ditinjau dari analisa keragaman ternyata pola ikatan pembuluh berpengaruh nyata terhadap nilai nisbah Muhlstep $(\mathrm{P}<0.05)$ (Lampiran 2). Berdasar uji Tuckey (Lampiran 3) untuk melihat lebih jauh posisi nisbah Muhlstep pada pola ikatan pembuluh ternyata nisbah pada pola 1 berbeda nyata dengan nilai nisbah muhlstep pada pola ikatan pembuluh 2, 3 dan 4 . Nilai-nilai nisbah Muhlstep pada bambu dengan pola ikatan pembuluh 2 sama dengan nilai nisbah Muhlstep pola 3 dan 4. Nisbah Muhlstep sebagaimana diuraikan sebelumnya merupakan nisbah antara luas penampang tebal dinding serabut dengan luas penampang lintang serabut. Semakin kecil nilai nisbah muhlstep berarti semakin besar diameter lumen sehingga sel semakin mudah menggepeng dan mempunyai daya lipat yang tinggi (tidak kaku). Pengamatan terhadap keseluruhan pola, nilai nisbah Muhlstep pada pola 1 paling kecil sehingga nilai nisbah Muhlstep pada pola 1 paling baik dibandingkan dengan pola-pola lain. Dengan nilai nisbah Muhlstep yang semakin kecil berarti pola 1 mempunyai diameter lumen yang besar. Memang diantara pola-pola lain (Tabel 1), diameter lumen pola 1 paling besar dengan dinding yang juga paling tipis sehingga sel akan dengan mudah pipih serta akan memiliki ketahanan tarik dan retak yang baik.

\section{B. Peluang Bambu pada Berbagai Pola sebagai Bahan Baku Pulp dan Kertas}

Hasil penelaahan dimensi serat dan nilai turunan serat bambu dari 4 macam pola yang dibandingkan standar (Lampiran 1) disajikan pada Tabel 3.

Pada Tabel 3 terlihat bahwa semua pola memiliki panjang serabut kelas 1 demikian pula daya tenunnya sementara untuk nilai dimensi turunan lainnya yaitu fleksibilitas, koefisien kekakuan, nisbah Runkel dan nisbah Muhlstep memiliki kelas kualitas III (dengan catatan bahwa pengelompokan ke dalam kelas III untuk nilai-nilai yang berada dan di bawah kelas III). Kalau setiap nilai turunan dikonversi ke dalam bentuk nilai maka sebenarnya seluruh pola pada bambu termasuk dalam kategori kelas II (bernilai 300) yang artinya kalau semua bahan tersebut dijadikan lembaran pulp (kertas) maka daya jalin serat cukup baik tetapi serat masih agak kaku sehingga sukar menggepeng dan kontak antar serat menjadi kurang efektif.

Kesesuaian indikasi tersebut perlu diuji lebih lanjut melalui pengolahannya menjadi pulp dan kertas, terutama terkait dengan porsi kerapatan ikatan pembuluh. Berdasarkan hasil 
penelitian Nuriyatin (2011) tentang sifat anatomi pada 8 jenis bambu, ternyata kerapatan ikatan pembuluh berturut-turut yang tertinggi ke yang terendah dimiliki oleh pola 1, pola 2, pola 4 dan pola 3 .

Tabel3. Hasil penetapan nilai serat bambu berdasar dimensi serat dan nilai turunannya 8 jenis bambu yang dikelompokan menjadi 4 macam pola mengacu kepada standar kriteria*)

Table3. Results of determination of values for bamboo fibre based on fiber dimensions and their derived values of 8 bamboos species further grouped into 4 patterns by referring to the criteria standard $\%$ ).

\begin{tabular}{|c|c|c|c|c|c|c|c|c|}
\hline \multirow{3}{*}{$\begin{array}{c}\text { Dimensi serat } \\
\text { dan nilai } \\
\text { turunannya } \\
\text { (Fibre dimensions } \\
\text { and their derivated } \\
\text { values) }\end{array}$} & \multicolumn{8}{|c|}{$\begin{array}{l}\text { Pola ikatan pembuluh pada batang bambu } \\
\text { (Patterns of vascular bundle arrangement in bamboo stem) }\end{array}$} \\
\hline & \multicolumn{2}{|c|}{$\begin{array}{c}\text { Pola (Pattern) } \\
1 \\
\end{array}$} & \multicolumn{2}{|c|}{$\begin{array}{c}\text { Pola (Pattern) } \\
2 \\
\end{array}$} & \multicolumn{2}{|c|}{$\begin{array}{c}\text { Pola (Pattern) } \\
3 \\
\end{array}$} & \multicolumn{2}{|c|}{$\begin{array}{c}\text { Pola (Pattern) } \\
4\end{array}$} \\
\hline & $\mathrm{Y}^{* *}$ & $\begin{array}{l}\text { Nilai } \\
\text { (value) }\end{array}$ & $\mathrm{Y}^{* *}$ & $\begin{array}{l}\text { Nilai } \\
\text { (value) }\end{array}$ & $\mathrm{Y}^{* *}$ & $\begin{array}{l}\text { Nilai } \\
\text { (value) }\end{array}$ & $\mathrm{Y}^{* *}$ & $\begin{array}{l}\text { Nilai } \\
\text { (value) }\end{array}$ \\
\hline $\begin{array}{l}\text { Panjang serat } \\
\text { (Fibre length), } \mu\end{array}$ & $>2000$ & 100 & $>2000$ & 100 & $>2000$ & 100 & $>2000$ & 100 \\
\hline $\begin{array}{l}\text { Daya tenun } \\
\text { (Felting power) }\end{array}$ & $>90$ & 100 & $>90$ & 100 & $>90$ & 100 & $>90$ & 100 \\
\hline $\begin{array}{l}\text { Fleksibilitas } \\
\text { (Flexibility) }\end{array}$ & $<0.5$ & 25 & $<0.5$ & 25 & $<0.5$ & 25 & $<0.5$ & 25 \\
\hline $\begin{array}{l}\text { Koefisien } \\
\text { kekakuan } \\
\text { (Rigidity coefficient) }\end{array}$ & $>0.15$ & 25 & $>0.15$ & 25 & $>0.15$ & 25 & $>0.15$ & 25 \\
\hline $\begin{array}{l}\text { Nisbah runkel } \\
\text { (Runkel ratio) }\end{array}$ & $>1$ & 25 & $>1$ & 25 & $>1$ & 25 & $>1$ & 25 \\
\hline $\begin{array}{l}\text { Nisbah muhlstep } \\
\text { (Mublstep ratio) }\end{array}$ & $>80$ & 25 & $>80$ & 25 & $>80$ & 25 & $>80$ & 25 \\
\hline $\begin{array}{l}\text { Total nilai } \\
\text { (Total value) }\end{array}$ & & 300 & & 300 & & 300 & & 300 \\
\hline
\end{tabular}

Keterangan (Remarks):

*) Lihat Lampiran 1 (Refer to Appendix 1), $\mu=$ Mikron/Micron

**) Angka rata-rata (Mean figure)

Hal ini terkait dengan porsi serat yang cenderung semakin menurun sedangkan jaringan parenkim semakin banyak. Meningkatnya jaringan parenkim akan meningkatkan konsumsi bahan kimia pemasak selama pengolahan pulp sehingga bila kondisi pemasakan sama akan menurunkan efektifitas bahan kimia dalam pemisahan serat (delignifikasi) menjadi pulp. Sebaliknya dengan porsi serat yang menurun maka pada kondisi pemasakan yang sama akan memungkinkan banyak serat terdegradasi sehingga rendemen pulp dan sifat kekuatan kertas menurun. Dengan demikian maka dugaan-dugaan tersebut perlu ditelaah kebenarannya melalui uji pengolahan pulp dan kertas. 
Hasil penelitian Fatriasari dan Hermiyati (2008) terhadap 6 jenis bambu sebagai bahan baku pulp dan kertas memberikan hasil dimana $83 \%$ bambu memiliki daya tenun kualitas I dengan sisanya termasuk kualitas II, sementara nilai turunan lainnya termasuk ke dalam kelas III. Hasil yang sama juga diungkapkan oleh Nuriyatin (2000) yang melakukan penelitian terhadap 5 jenis bambu namun dengan nilai daya tenun semuanya termasuk ke dalam klas I. Di dalam pelaksanaan di lapangan pada umumnya bahan baku pembuatan pulp dan kertas merupakan perpaduan antara berbagai macam ukuran serabut sehingga diharapkan akan diperoleh hasil yang lebih solid dalam pembentukan lembaran (Casey 1980).

\section{KESIMPULAN}

Penggunaan bambu sebanyak 8 jenis sebagai bahan baku pulp dan kertas yang terwakili mulai dari bambu dengan pola ikatan pembuluh 1 sampai 4 memberikan hasil yang sama, yaitu setiap pola menghasilkan daya tenun kelas I sementara untuk nilai fleksibilitas, koefisien kekakuan, nisbah runkel dan nisbah muhlstep semuanya termasuk ke dalam kelas III. Pengamatan lebih mendalam terhadap karakter pola ikatan pembuluh terkait dengan perannya sebagai bahan baku bambu terlihat bahwa bambu pada pola 1 mempunyai ciri tertentu yaitu memiliki fleksibilitas yang paling tinggi dibandingkan dengan pola-pola lain juga mempunyai nilai koefisien kekakuan serta nisbah Runkel yang paling rendah dibandingkan dengan pola-pola lain. Pola ikatan pembuluh 4 mempunyai ciri yaitu memiliki panjang serabut dan daya tenun yang paling tinggi dibandingkan dengan pola-pola lain.

Berdasarkan telaahan dimensi serat dan turunannya dibandingkan dengan persyaratan standar maka keseluruhan serat bambu dari pola 1 hingga 4 termasuk katagori kelas II (nilai 300). Dengan demikian berindikasi cukup baik untuk digunakan sebagai bahan baku pulp dan kertas. Selanjutnya untuk mengetahui kebenaran indikasi tersebut perlu penelaahan lebih lanjut melalui pengolahan bambu (mulai pola ke 1 hingga ke 4) menjadi pulp dan kertas.

\section{DAFTAR PUSTAKA}

Anonim 1976. Penentuan dimensi serat dan nilai turunannya pada kayu dan bahan berserat lingo-selulosa menurut cara LPHH (Lembaga Penelitian Hasil Hutan). Laporan LPHH No. 75. Bogor.

Casey JP. 1980. Pulp and Paper Vol. I. New York: Interscience Publishers.

Fatriasari W, Hermiati E. 2008. Analisis morfologi serat dan sifat fisis-kimia pada enam jenis bambu sebagai bahan baku pulp dan kertas. J Ilm Teknol Has Hut 1(2): 67-72.

Grosser D, Liese W. 1971. On the anatomy of Asian bamboos, with special reference to their vascular bundles. W Sci Technol V 5: 290-312.

Haygreen JG, Bowyer JL. 1996. Hasil Hutan dan Ilmu Kayu Suatu Pengantar. Yogyakarta: Gadjah Mada University Press.

Lapierre L, Bouchard J, Berry R. 2006. On the relation between fibre length, cellulose chain length and pulp viscosity of a softwood sulfite pulp. Hoizforschung, V 60:372-377. 
Lybeer B, Van Acker J, Goetghebeur P. 2006. Variability in fibre and parenchyma cell walls of temperate and tropical bamboo culms of different ages. Springer-Verlag

Mohmod AL, Amin A, Kasim J, Jusuh MZ. 1972. Effect of anatomical characteristics on the physical and mechanical properties of Bambusa blumeana. J Tropc For Sci 6(2): 159 170.

Nuriyatin N. 2000. Studi analisa sifat-sifat dasar bambu pada beberapa tujuan penggunaan [tesis]. Bogor: Program Pascasarjana, Institut Pertanian Bogor.

Nuriyatin N. 2011. Sifat anatomi 8 jenis bambu [bagian draft disertasi]. Bogor: Program Pascasarjana, Institut Pertanian Bogor.

Pasaribu RA, Silitonga T. 1974. Pulp campuran kayu daun lebar dan bambu. Laporan (report) no 35, Lembaga Penelitian Hasil Hutan, Direktorat Jenderal Kehutanan, Departemen Pertanian. Bogor.

Patt R, Kordsachia O, Fehr J. 2005. European hardwoods versus Eucalyptus globules as a raw material for pulping.

Rowell RM, Young RA, Rowell JK. 1997. Paper and Composites from Agro-based Resources. New York: Lewis Publishers.

Sass JE. 1951. Botanical Microtechnique. Iowa: The Iowa State College Press.

Stephenson JN. 19952 Pulp and Paper Manufacture, Vol. I \& II. Mc Graw-Hill Book Co, Inc. New York-Toronto-London.

Xu F, Zhong XC, Sun RC, Lu Q, Jones GL. 2005. Chemical composition, fibre morphology, and pulping of $\mathrm{P}$ bolleana Lauche. 
Lampiran 1. Kriteria serabut kayu Indonesia dan bahan berlignoselulosa lain untuk bahan baku pulp dan kertas

Appendix 1. Indonesia fiber wood criteria and other ligno-cellulose as raw material for pulp and paper

\begin{tabular}{|c|c|c|c|c|c|c|c|}
\hline \multirow[t]{2}{*}{ No } & \multirow{2}{*}{$\begin{array}{c}\text { Sifat serat } \\
\text { (Fiber } \\
\text { characteristics) }\end{array}$} & \multicolumn{2}{|c|}{$\begin{array}{l}\text { Kelas } \\
\text { (Class) I }\end{array}$} & \multicolumn{2}{|c|}{$\begin{array}{l}\text { Kelas } \\
\text { (Class) II }\end{array}$} & \multicolumn{2}{|c|}{$\begin{array}{l}\text { Kelas } \\
\text { (Class) III }\end{array}$} \\
\hline & & Syarat & Nilai & Syarat & Nilai & Syarat & Nilai \\
\hline 1 & $\begin{array}{l}\text { Panjang (Fiber } \\
\text { length), } \mu\end{array}$ & $>2000$ & 100 & $1000-2000$ & 50 & $\begin{array}{c}< \\
1000\end{array}$ & 25 \\
\hline 2 & $\begin{array}{l}\text { Perbandingan } \\
\text { Runkel } \\
\text { (Runkel ratio) }\end{array}$ & $<0.25$ & 100 & $0.25-0.5$ & 50 & $0.5-1$ & 25 \\
\hline 3 & $\begin{array}{l}\text { Daya Tenun } \\
\text { (Felting power) }\end{array}$ & $>90$ & 100 & $50-90$ & 50 & $<50$ & 25 \\
\hline 4 & $\begin{array}{l}\text { Perbandingan } \\
\text { Muhlsteph } \\
\text { (Mublstep ratio) }\end{array}$ & $<30$ & 100 & $30-60$ & 50 & $\begin{array}{c}60- \\
80\end{array}$ & 25 \\
\hline 5 & $\begin{array}{l}\text { Perbandingan } \\
\text { Fleksibilitas } \\
\text { (Flexibility ratio) }\end{array}$ & $>0.80$ & 100 & $0.5-0.8$ & 50 & $<0.5$ & 25 \\
\hline 6 & $\begin{array}{l}\text { Koefisien } \\
\text { kekakuan } \\
\text { (Rigidity } \\
\text { coefficient) }\end{array}$ & $<0.10$ & 100 & $0.10-0.15$ & 50 & $>0.15$ & 25 \\
\hline & Selang (Range) & \multicolumn{2}{|c|}{$450-600$} & \multicolumn{2}{|c|}{$225-449$} & \multicolumn{2}{|c|}{$<225$} \\
\hline
\end{tabular}

Sumber / Source: Anonim (1976) 
Lampiran 2. Analisis sidik ragam dimensi serabut bambu dan nilai turunannya Appendix 2. Analysis of variances on fiber dimensions of bamboo and their derived values

a. Panjang serabut versus pola ikatan pembuluh bamboo (Fiber length against patterns of bamboo vascular bundle)

\begin{tabular}{|l|l|l|l|l|l|}
\hline \multicolumn{1}{|c|}{$\begin{array}{c}\text { Sumber keragaman } \\
\text { (source of variance) }\end{array}$} & $\begin{array}{l}\text { Db } \\
(d f)\end{array}$ & $\begin{array}{c}\text { Jumlah } \\
\text { kuadrat } \\
\text { (sum of } \\
\text { squares) }\end{array}$ & $\begin{array}{c}\text { Kuadrat } \\
\text { tengah } \\
\text { (mean square) }\end{array}$ & $\begin{array}{c}\text { F-hitung } \\
\text { (calculated) }\end{array}$ & $\begin{array}{c}\text { Peluang } \\
(P)\end{array}$ \\
\hline $\begin{array}{l}\text { Total } \\
\text { Pola (Pattern) } \\
\text { Error }\end{array}$ & $\begin{array}{l}57 \\
3\end{array}$ & $\begin{array}{l}21544072 \\
8798305 \\
12745766\end{array}$ & 236033 & 12,43 & $0,000^{*}$ \\
\hline $\begin{array}{l}\text { Koefisien keragaman/ } \\
\text { Coefficient of variatin }(\%)\end{array}$ & - & & & 40,84 & \\
\hline
\end{tabular}

*berbeda nyata (Significantty)

b. Daya tenun versus pola ikatan pembuluh bambu (Felting power against patterns of bamboo vascular bundle)

\begin{tabular}{|l|l|l|l|l|l|}
\hline \multicolumn{1}{|c|}{$\begin{array}{c}\text { Sumber keragaman } \\
\text { (Source of variance) }\end{array}$} & $\begin{array}{c}\mathrm{Db} \\
(d f)\end{array}$ & $\begin{array}{c}\text { Jumlah } \\
\text { kuadrat } \\
\text { (Sum of } \\
\text { squares) }\end{array}$ & $\begin{array}{c}\text { Kuadrat } \\
\text { tengah } \\
\text { (Mean square) }\end{array}$ & $\begin{array}{c}\text { F-hitung } \\
\text { (Calculated) }\end{array}$ & $\begin{array}{c}\text { Peluang } \\
(P)\end{array}$ \\
\hline $\begin{array}{l}\text { Total } \\
\text { Pola (Pattern) }\end{array}$ & 57 & $\begin{array}{l}76418 \\
15666\end{array}$ & 5222 & 4,64 & $0,006^{*}$ \\
Error & 54 & 60752 & 1125 & 20,50 & \\
\hline $\begin{array}{l}\text { Koefisien keragaman/ } \\
\text { Coefficient of variatin }(\%)\end{array}$ & - & & & & \\
\hline
\end{tabular}

*berbeda nyata (significantty)

c. Fleksibilitas versus pola ikatan pembuluh bambu (Flexibility ratio against patterns of bamboo vascular bundle)

\begin{tabular}{|l|l|l|l|l|l|}
\hline \multicolumn{1}{|c|}{$\begin{array}{c}\text { Sumber keragaman } \\
\text { (Source of varianc) }\end{array}$} & $\begin{array}{c}\text { Db } \\
(d f)\end{array}$ & $\begin{array}{c}\text { Jumlah } \\
\text { kuadrat } \\
\text { (Sum of } \\
\text { squares) }\end{array}$ & $\begin{array}{c}\text { Kuadrat } \\
\text { tengah } \\
\text { (Mean square) }\end{array}$ & $\begin{array}{c}\text { F-hitung } \\
\text { (Calculated) }\end{array}$ & $\begin{array}{c}\text { Peluang } \\
(P)\end{array}$ \\
\hline $\begin{array}{l}\text { Total } \\
\text { Pola (Pattern) }\end{array}$ & $\begin{array}{l}57 \\
\text { Error }\end{array}$ & $\begin{array}{l}0,28806 \\
0,05641\end{array}$ & 0.01880 & 4,38 & $0,008^{*}$ \\
\hline $\begin{array}{l}\text { Koefisien keragaman/ } \\
\text { Coefficient of variatin (\%) }\end{array}$ & - & 0,23166 & 0.00429 & 19,58 & \\
\hline
\end{tabular}

*berbeda nyata (Significantty) 
d. Koefisien kekakuan versus pola ikatan pembuluh bambu (Rigidity coefficient agains patterns of bamboo vascular bundle)

\begin{tabular}{|c|c|c|c|c|c|}
\hline $\begin{array}{l}\text { Sumber keragaman } \\
\text { (Source of variance) }\end{array}$ & $\begin{array}{l}\mathrm{Db} \\
(d f)\end{array}$ & $\begin{array}{l}\text { Jumlah } \\
\text { kuadrat } \\
\text { (Sum of } \\
\text { squares) }\end{array}$ & $\begin{array}{c}\text { Kuadrat } \\
\text { tengah } \\
\text { (Mean square) }\end{array}$ & $\begin{array}{l}\text { F-hitung } \\
\text { (Calculated) }\end{array}$ & $\begin{array}{l}\text { Peluang } \\
\qquad(P)\end{array}$ \\
\hline $\begin{array}{l}\text { Total } \\
\text { Pola (Pattern) } \\
\text { Error }\end{array}$ & $\begin{array}{l}57 \\
3 \\
54\end{array}$ & $\begin{array}{l}76418 \\
15666 \\
60752\end{array}$ & $\begin{array}{l}5222 \\
1125\end{array}$ & 4,38 & $0,006^{*}$ \\
\hline $\begin{array}{l}\text { Koefisien keragaman/ } \\
\text { Coefficient of variatin }(\%)\end{array}$ & - & & & 19,58 & \\
\hline
\end{tabular}

*berbeda nyata (Significantty)

e. Perbandingan runkel versus pola ikatan pembuluh bambu (Runkel ratio agains patterns of bamboo vascular bundle)

\begin{tabular}{|c|c|c|c|c|c|}
\hline $\begin{array}{l}\text { Sumber keragaman } \\
\text { (source of variance) }\end{array}$ & $\begin{array}{l}\mathrm{Db} \\
(d f)\end{array}$ & $\begin{array}{l}\text { Jumlah } \\
\text { kuadrat } \\
\text { (sum of } \\
\text { squares) }\end{array}$ & $\begin{array}{c}\text { Kuadrat } \\
\text { tengah } \\
\text { (mean square) }\end{array}$ & $\begin{array}{l}\text { F-hitung } \\
\text { (calculated) }\end{array}$ & $\begin{array}{l}\text { Peluang } \\
\qquad(P)\end{array}$ \\
\hline $\begin{array}{l}\text { Total } \\
\text { Pola (Pattern) } \\
\text { Error }\end{array}$ & $\begin{array}{l}57 \\
3 \\
54\end{array}$ & $\begin{array}{l}132,91 \\
16,96 \\
115,96\end{array}$ & $\begin{array}{l}5,65 \\
2,15\end{array}$ & 2,63 & 0,059 \\
\hline $\begin{array}{l}\text { Koefisien keragaman/ } \\
\text { Coefficient of variatin }(\%)\end{array}$ & - & & & 12,76 & \\
\hline
\end{tabular}

f. Nisbah muhlstep versus pola ikatan pembuluh bambu (Muhlstep ratio against patterns of bamboo vascular bundle)

\begin{tabular}{|c|c|c|c|c|c|}
\hline $\begin{array}{c}\text { Sumber keragaman } \\
\text { (source of variance) }\end{array}$ & $\begin{array}{l}\mathrm{Db} \\
(d f)\end{array}$ & $\begin{array}{l}\text { Jumlah } \\
\text { kuadrat } \\
\text { (sum of } \\
\text { squares) }\end{array}$ & $\begin{array}{c}\text { Kuadrat } \\
\text { tengah } \\
\text { (mean square) }\end{array}$ & $\begin{array}{l}\text { F-hitung } \\
\text { (calculated) }\end{array}$ & $\begin{array}{l}\text { Peluang } \\
\qquad(P)\end{array}$ \\
\hline $\begin{array}{l}\text { Total } \\
\text { Pola (Pattern) } \\
\text { Error }\end{array}$ & $\begin{array}{l}57 \\
3 \\
54\end{array}$ & $\begin{array}{l}745,7 \\
162,9 \\
582,7\end{array}$ & $\begin{array}{l}54,3 \\
10,8\end{array}$ & 5,03 & $0,004 *$ \\
\hline $\begin{array}{l}\text { Koefisien keragaman/ } \\
\text { Coefficient of variatin }(\%)\end{array}$ & - & & & 20,85 & \\
\hline
\end{tabular}

*berbeda nyata (Significantly) 
Lampiran 3. Uji beda jarak beda nyata rata-rata nilai dimensi serat bambu dan nilai turunannya (Prosedur Tukey)

Appendix 3. Significant different range test on means of fiber dimensions and their derived value for bamboo (Tukey procedure)

\begin{tabular}{|c|c|c|c|c|c|c|}
\hline No & $\begin{array}{c}\text { Sifat } \\
\text { (Properties) }\end{array}$ & $\begin{array}{l}\text { Perlakuan } \\
\text { (Treatment) }\end{array}$ & \multicolumn{4}{|c|}{$\begin{array}{l}\text { Nilai rata-rata yang dibandingkan } \\
\text { (Comparison of mean value s) }\end{array}$} \\
\hline 1 & $\begin{array}{l}\text { Panjang serabut } \\
\text { (Fiber length) }\end{array}$ & $\begin{array}{c}\text { Pola } \\
\text { (Pattern) }\end{array}$ & $\begin{array}{l}\text { Pola } 1 \\
2373,6\end{array}$ & $\begin{array}{c}\text { Pola } 2 \\
2571,4\end{array}$ & $\begin{array}{l}\text { Pola } 3 \\
2812,1\end{array}$ & $\begin{array}{r}\text { Pola } 4 \\
3734,5\end{array}$ \\
\hline 2 & $\begin{array}{l}\text { Daya tenun } \\
\text { (Felting power) }\end{array}$ & $\begin{array}{c}\text { Pola } \\
\text { (Pattern) }\end{array}$ & $\begin{array}{l}\text { Pol a } 1 \\
140,29\end{array}$ & $\begin{array}{c}\text { Pola } 2 \\
162,22\end{array}$ & $\begin{array}{l}\text { Pola } 3 \\
166,50\end{array}$ & $\begin{array}{c}\text { Pola } 4 \\
205,37\end{array}$ \\
\hline 3 & $\begin{array}{l}\text { Fleksibilitas } \\
\text { (Flexibility) }\end{array}$ & $\begin{array}{c}\text { Pola } \\
\text { (Pattern) }\end{array}$ & $\begin{array}{r}\text { Pola } 4 \\
0,20871\end{array}$ & $\begin{array}{r}\text { Pola } 2 \\
0,21705\end{array}$ & $\begin{array}{r}\text { Pola } 3 \\
0,22281\end{array}$ & $\begin{array}{r}\text { pola } 1 \\
0,32854\end{array}$ \\
\hline 4 & $\begin{array}{l}\text { Koefisien kekakuan } \\
\text { (rigidity coefficient) }\end{array}$ & $\begin{array}{c}\text { Pola } \\
\text { (Pattern) }\end{array}$ & $\begin{array}{r}\text { Pola } 1 \\
0,33573\end{array}$ & $\begin{array}{r}\text { Pola } 3 \\
0,38860\end{array}$ & $\begin{array}{r}\text { Pola } 2 \\
0,39148\end{array}$ & $\begin{array}{r}\text { pola } 4 \\
0,39561\end{array}$ \\
\hline 5 & $\begin{array}{l}\text { Perbandingan runkel } \\
\text { (Runkel ratio) }\end{array}$ & $\begin{array}{c}\text { Pola } \\
\text { (Pattern) }\end{array}$ & $\begin{array}{l}\text { Pola } 1 \\
2,125\end{array}$ & $\begin{array}{l}\text { Pola } 2 \\
3,788\end{array}$ & $\begin{array}{l}\text { Pola } 3 \\
4,025\end{array}$ & $\begin{array}{l}\text { Pola } 4 \\
4,245\end{array}$ \\
\hline 6 & $\begin{array}{l}\text { Nisbah muhlstep } \\
\text { (Mublstep ratio) }\end{array}$ & $\begin{array}{c}\text { Pola } \\
\text { (Pattern) }\end{array}$ & $\begin{array}{l}\text { Pola } 1 \\
88,939\end{array}$ & $\begin{array}{l}\text { Pola } 3 \\
94,478\end{array}$ & $\begin{array}{l}\text { Pola } 2 \\
95,093\end{array}$ & $\begin{array}{l}\text { Pola } 4 \\
95,237\end{array}$ \\
\hline
\end{tabular}

Keterangan (Remark): Nilai rat-rata yang diberi garis bawah tidak berbedanyata(Mean value with underline are from each other) 